\title{
Issues and Problems of Muslim Minorities in Europe (A Case of British Muslim Community)
}

* Muhammad Muddasar

** Dr. Riaz Ahmad Saeed

\section{ABSTRACT:}

This piece of paper examines the existing position of Muslim minority in England with reference to their challenges, issues and problems, as well as this study reveals the solution and recommendations to solve these issues. The Muslims are one of the biggest communities of Europe in Britain. They are living and settled here since long. They have many important contributions in every field of life even the sitting Mayer of London is a Muslim. It doesn't mean they have no problem. They are facing lots issues and discrimination in every field of life, especially they are being deprived in the field of economy. Practising Muslims face a wide variety of challenges, even they do not have enough freedom of religion, freedom to offer open prayer, build mosques, keep beard and wear traditional dress at work. Women wearing the veil caused all kinds of issues and are practically banned for certain jobs (e.g. teaching and the police). Islam has dietary requirements that can make deciding what's acceptable and not acceptable but at work all Muslim workers are not being offered Halal food. Islam is deadly against interest but in the UK the Muslims are unable to avoid themselves from it as no job is interest free. It is perceived that the Muslim minority is politically, economically and socially deprived in the UK. Thus, it's the dire need to solve the problems of the Muslim communities in all over the West especially in Britain. The analytical and critical research methodology is adopted with mix method approach in this study.

Key Words: Europe, British Muslim Community, Discrimination, Issues, Challenges. Introduction:

The Muslims started living in England about three hundred years ago. They consider England as their motherland and take part in the progress of the country as like native citizens. They are peace loving and want this country peaceful and developed for themselves and their children and for their generations yet unborn. History is itself a witnes that they have cooperated a lot in the field of economic, peace, education and in politics too. Most of them have citizenship of England but in spite of these collaborations, they are being treated as guest workers from the native citizens and from govt: side too. After 9/11 terrorist attack, the Muslims around the world are being considered as terrorist, especially in Britain, the local population and government authorities consider Muslims as security risk for their country. The government has banned many Muslim NGO,s and welfare centres by saying that they collect funds for supporting terrorist financially. The Government is launching different laws by pretending for the

"PhD Scholar, Department of Islamic Studies NUML, Islamabad / Lecturer Givernment Degree College Dinga Gujrat. muddasarwarraich22@gmail.com

***ecturer, Department of Islamic Studies, NUML, Islamabad. riazussaeed@ gmail.com 
security of the citizens but the purposes of these laws proves discrimination to the Muslim minority in the country.

The religious scholars and persons who have strong impact factor in the Muslims community are being kept under observation to detect their activities. All these acts have sensitized the Muslim minority in England that really love their country. The terrorism is being patched with Islam after 9/11 and train bomb attacks in England. Islam is the religion peace and harmony and The Muslims are a peaceloving nation. These circumstances create of lot of issues for Muslim minorities in so-called multi-ethnic and secular western countries especially in UK tertiary. In addition, the increasing trend of Islamophobia after $9 / 11$ and weak laws and uninteresting behaviour of law enforcement agencies is making this issue more severe. This paper highlights the major problems of existing the Muslim minority in UK with suitable suggestions to overcome these issues.

\section{Historical Background:}

The history of Muslims settlement in England is old enough, about three hundred years ago they started to settle here and with the passage of time their population increased until Islam became the second largest religion in England after Christianity. First of all, some Yemeni fishermen came here.

"Muslims first arrived in Britain over 300 years ago. Yemeni soldiers arrived after the opening of the Suez Canal, formed some of the oldest Muslim Communities in the Port cities of London Cardiff, Liverpool and Southfields" ${ }^{1 " .}$

The British Muslim minority has diverse racial, national and ethnic background. According to the Census of 2011:

"Three quarter of the Muslims (74 Percent) is from Asian Ethnic Background, predominantly the Pakistani (43\%) and Bangladeshi (16\%) Indians (8\%) and other Asian (6\%). Eleven Percent white ethnic group of which $4 \%$ is of white British origin and 7 Present is from other white background... 6 Percent of the Muslims are from black African origin, mainly from North and East Africa..... then are also estimated to be up to 10,000 converters to Islam in Britain". ${ }^{2}$

\section{The Pew Research Centre Report 2011 manifest:}

The Muslim population in 2010 was $4.8 \%$ of the total population England was $2960000^{3}$. Total population of England according to religious division in 2011is given below.

\begin{tabular}{|l|l|l|}
\hline Religion & Total Population & Percent \\
\hline Christian & $33,243,175$ & $59.3 \%$ \\
\hline Muslims & $2,706,066$ & $4.8 \%$ \\
\hline Hindu & 816,633 & $1.5 \%$ \\
\hline Jewish & 263,346 & $0.5 \%$ \\
\hline Buddhist & 247,743 & $0.4 \%$ \\
\hline Any of the Religion & 240,530 & $0.4 \%$ \\
\hline No religion & $14,097,229$ & $25.1 \%$ \\
\hline Religion not stated & $4,038,032$ & $7.2 \%$ \\
\hline All & $56,075,912$ & $100 \%$ \\
\hline
\end{tabular}


The census of 2011 reveales that the Muslim population was 2706066 in England and Wales which was 1546626 in 2001.It shows increase of 74\% in the Muslim population as number of 1159440 persons increased. Islam has become the second largest religion in England. According to"Pew Research Centre"5 in 2050 the Muslim's population will become majority in many cities of England and the native Christians will become minority.

\section{Muslim Population Belongs to Different Ethnic Groups}

Change of population from 2001-2011according to their ethnic group

\begin{tabular}{|l|l|l|l|l|lr|}
\hline Muslim & \multicolumn{3}{|l}{ Muslim } & \multicolumn{3}{l|}{ Population Change } \\
\hline Ethnic Group & 2001 & $\%$ & 2011 & $\%$ & $2001-2011$ & $\%$ \\
\hline White & 179,773 & $11.6 \%$ & 2010620 & $7.8 \%$ & 30847 & $2.7 \%$ \\
\hline British & 63042 & $4.1 \%$ & 77272 & $2.9 \%$ & 14230 & $1.2 \%$ \\
\hline Irish & 890 & $0.1 \%$ & 1914 & $0.1 \%$ & 1024 & $0.1 \%$ \\
\hline Other White & 115841 & $7.5 \%$ & 131,434 & $4.9 \%$ & 15593 & $1.3 \%$ \\
\hline Mixed & 64262 & $4.2 \%$ & 102582 & $3.8 \%$ & 38320 & $3.3 \%$ \\
\hline $\begin{array}{l}\text { White \& Black } \\
\text { Caribean }\end{array}$ & 1385 & $0.1 \%$ & 5384 & $0.2 \%$ & 3999 & $0.3 \%$ \\
\hline White \& Black African & 10523 & $0.7 \%$ & 15681 & $0.6 \%$ & 5158 & $0.4 \%$ \\
\hline White and Asian & 30397 & $2.0 \%$ & 49689 & $1.8 \%$ & 19292 & $1.7 \%$ \\
\hline Other Mixed & 21957 & $1.4 \%$ & 31828 & $1.2 \%$ & 9871 & $0.9 \%$ \\
\hline Asian & 1139817 & $73.7 \%$ & 1830560 & $67.6 \%$ & 690743 & $59.6 \%$ \\
\hline Indian & 131662 & $8.5 \%$ & 197161 & $7.3 \%$ & 65499 & $5.6 \%$ \\
\hline Pakistani & 657680 & $42.5 \%$ & 102845 & $38.0 \%$ & 370779 & $32.0 \%$ \\
\hline Bangladeshi & 259710 & $16.8 \%$ & 402428 & $14.9 \%$ & 142718 & $12.3 \%$ \\
\hline Chinese & 752 & $0.0 \%$ & 8027 & $0.3 \%$ & 7275 & $0.6 \%$ \\
\hline Other Asian & 90013 & $5.8 \%$ & 194485 & $7.2 \%$ & 104472 & $9.0 \%$ \\
\hline All Black & 106345 & $6.9 \%$ & 272015 & $10.1 \%$ & 165670 & $14.3 \%$ \\
\hline Black Caribean & 4477 & $0.3 \%$ & 7345 & $0.3 \%$ & 1868 & $0.2 \%$ \\
\hline Black African & 96136 & $6.2 \%$ & 207201 & $7.7 \%$ & 111065 & $9.6 \%$ \\
\hline Other Black & 5732 & $0.4 \%$ & 57469 & $2.1 \%$ & 51737 & $4.5 \%$ \\
\hline Other & 56429 & $3.6 \%$ & 290289 & $10.7 \%$ & $2333860.20 .2 \%$ \\
\hline Arale & ------- & ----- & 178195 & $6.6 \%$ & 178195 & $5.4 \%$ \\
\hline Any other ethnic & 56429 & $3.6 \%$ & 112094 & $4.1 \%$ & 55665 & $4.8 \%$ \\
\hline All & 1546626 & & 2706066 & & \multicolumn{1}{|c|}{115440} & 6 \\
\hline
\end{tabular}

After exploring the history of Muslims settlement in England now it is revealed that how Muslims are facing discriminated behave there. The Muslims are living here in the worst conditions than in France. Although the Muslims are living here more than three centuries and also participating in the development and progress of the country but they are not considered equal to native citizens. They have to face a lot of problems in their routine life. The Muslim community is civilized and peace loving. They cooperate with local authorities like other citizens but they have to face unequal and discriminated behaviour from public and government too. The government and the native public are unhappy with the Muslims because Islam is 
spreading there very rapidly and Muslim's birth rate is higher than native public. The government and the private NGO'S are in fear that if the Muslim population and trend of embracing Islam remains constant, a time will come when the Muslims will become majority in different cities of England. They want to control the Muslim population at any price, so they have started negative propaganda against the Muslims and Islam. They say that Muslims are terrorist and extremist and Islam preaches terrorism to its followers. They want that the Muslims should not follow the teachings of Islam or they should leave the country and go back to their homeland. The British media is propagating against the Muslims and Islam, so the local population considers the Muslims a danger for the country.

\section{Discrimination in Multidimensional Fields of Life: Housing:}

The Muslims are facing discrimination in housing facility as $2.2 \%$ people of total population are homeless in England but the ratio in the Muslims is 5.1\%. This is an evidence that the Muslim minority is facing discrimination in basic needs and necessities of life in the UK. They are being treated as other local citizens are provided facilities by the government. This is the thing which exposes the government of England which claims that we offer equal opportunities to all groups of society. This is against the UN charter of fundamental rights of minorities. This is reality that minorities have no equal rights in the UK in their practical life and Muslims are the most deprived among other groups of minorities in England.

\begin{tabular}{|l|l|l|l|l|}
\hline Establishment Type & All & \multicolumn{1}{|c|}{$\%$} & Muslims & \multicolumn{1}{|c|}{} \\
\hline Prison Service & 51659 & $5.5 \%$ & 4838 & $15.5 \%$ \\
\hline Approved Service and other & 1150 & $0.1 \%$ & 81 & $0.3 \%$ \\
\hline $\begin{array}{l}\text { Detention Centre and } \\
\text { Detention }\end{array}$ & $1.2 \%$ & 1364 & $4.4 \%$ \\
\hline $\begin{array}{l}\text { Hostels or Temporary Shelters for } \\
\text { the homeless }\end{array}$ & 20868 & $2.2 \%$ & 1587 & $\begin{array}{l}5.1 \% \\
7\end{array}$ \\
\hline
\end{tabular}

\section{Unjustifiable Interrogation and Prison:}

According to the data of the ministry of justice, the total number of prisoners in England is 86067 which is $0.15 \%$ of total population of the UK but $4.8 \%$ of total population of the Muslims. Portion of Muslim prisoners is $13 \%$ of total prisoners in the UK which shows a huge difference that $0.42 \%$ Muslims are in prison. The Muslims are being targeted due to their religion as the report under shows:

\section{Prison Population by religion:}

\begin{tabular}{|l|l|l|l|}
\hline Religious Group & $\begin{array}{l}\text { Prison } \\
\text { Population }\end{array}$ & $\begin{array}{l}\text { Prison Population as of } \\
\text { All Prison Population }\end{array}$ & $\begin{array}{l}\text { Religious Group } \\
\text { Prison Population\% }\end{array}$ \\
\hline Christian & 43176 & 50.2 & 0.13 \\
\hline Muslims & 11248 & 13.1 & 0.42 \\
\hline Hindu & 456 & 0.5 & 0.06 \\
\hline Jewish & 777 & 0.9 & 0.18 \\
\hline Buddhist & 1756 & 2.0 & 0.67 \\
\hline
\end{tabular}




\begin{tabular}{|l|l|l|l|}
\hline Sikh & 252 & 0.3 & 0.10 \\
\hline Other religious Group & 1077 & 1.3 & 0.45 \\
\hline No Religion & 25269 & 29.4 & 0.18 \\
\hline Not recorded & 2037 & 2.4 & 0.05 \\
\hline All & 86067 & & $0.15^{8}$ \\
\hline
\end{tabular}

Day by day incidents of arresting and interrogating the Muslims without any reason are increasing. This report exposes how the number of Muslim prisoners is rapidly increasing as compared to others. "In 2002 there were over 4,000 Muslim prisoners in UK representing some 9\% of the total Prison Population. Approximately $65 \%$ of Muslim Prisoners were men aged between 18 and 30 years."

The Muslim prisoners have been deprived of their basic human rights according to international human rights charter for minorities of the United Nation Organization Decmber 1992. After 9/11 the Muslims are being considered danger for the peace of the West and they are treated unequally so that they may go back to their home countries. Mostly on public places, when they are with their families, they have to face hateful comments and people raise slogans against the Muslims and Islam. It is observed that while travelling, the Muslim minority find themselves insecure at bus stations and airports they are stopped and kept under police custody saying that they looking like terrorists if they have beard and cap on their head. The women who cover their body according to the teaching of Islam are misbehaved at public places like market, visiting places and workplaces too. The Muslim prisoners are not allowed to perform prayers on time even during the holy month of Ramadan which is very special for the Muslims.

As this report shows: "It has been reported that the Muslim Prisoners have been unable to perform their prayers on time or to regulate their meal-times during Ramadan (the Muslims month of fasting). Lack of provision of halal food in prisons has been an issue reported on many occasions in the British Muslims Monthly Survey. ${ }^{\text {", }}$

This is against international law to prohibit anyone to perform his religious rites. The Muslim imams have to face insulting behave of prison officers when they go for spiritual training of the Muslim prisoners. Prison officers humiliate those imams due to their traditional dress and even some time they do not allow them to meet prisoners until they wear non-traditional dress.

"The Muslims imams were the target of Prison Officers' Racism and bullying. Imams were made to stand in line with inmates and denied access to prison keys which were given to chaplain. Attitude towards the imams only improved when they made the effort to fit in, for example, by wearing 'non-traditional' clothes. ${ }^{8}$

Moreover, the Islamic law and UN Law stated that the fundamental rights of human being can never be quitted or denied even if a person commits a heinous crime but in the prisons of England the Muslim prisoners are not to perform their religious rites. The Muslim imams who visit prisons to preach the Muslim prisoner for the right path are insulted and degraded by the prison staff is illegal. Muslims face multiple types 
of deprivation while living in England especially in the field of economy, health, education and housing.

According to the research of (LAD) Local Authority Districts:

The Muslims and Deprivations:

(IDM) INDEX OF MULTIPLE DEPRIVATION

\begin{tabular}{|l|l|l|l|l|}
\hline $\begin{array}{l}\text { 10\% Most Deprived Local } \\
\text { Authority Districts- } \\
\text { England }\end{array}$ & $\begin{array}{l}\text { Average } \\
\text { (IMD)2010 }\end{array}$ & All & $\begin{array}{l}\text { Muslim } \\
\text { Population }\end{array}$ & $\begin{array}{l}\text { Muslim Population } \\
\text { as of of All } \\
\text { Population }\end{array}$ \\
\hline Liverpool & $43.4 \%$ & 466415 & 15209 & 3.3 \\
\hline Hackeny & $42.9 \%$ & 246270 & 34727 & 14.1 \\
\hline New ham & $41.1 \%$ & 307984 & 98456 & 32.0 \\
\hline Manchester & $41.0 \%$ & 503127 & 79496 & 15.8 \\
\hline Knowsley & $40.4 \%$ & 145893 & 435 & 0.3 \\
\hline Black pool & $39.6 \%$ & 142065 & 1061 & 0.7 \\
\hline Tower Hamlets & $37.6 \%$ & 254096 & 87696 & 34.5 \\
\hline Middlesbrough & $37.5 \%$ & 138412 & 9757 & 7.0 \\
\hline Birmingham & $37.5 \%$ & 1073045 & 234411 & 21.8 \\
\hline Kingston upon Hill & $37.3 \%$ & 256406 & 5447 & 2.1 \\
\hline Burnely & $37.0 \%$ & 87059 & 8580 & 9.9 \\
\hline Sand well & $36.1 \%$ & 308063 & 25251 & 8.2 \\
\hline Haringey & $35.9 \%$ & 254926 & 36130 & 14.2 \\
\hline Islington & $35.4 \%$ & 206125 & 19521 & 9.5 \\
\hline Waltham Forest & $35.3 \%$ & 258249 & 56541 & 21.9 \\
\hline Stoke on Trent & $35.2 \%$ & 249008 & 14993 & 6.0 \\
\hline Blackburn & $35.2 \%$ & 147489 & 39817 & 27.0 \\
\hline Sanford & $34.7 \%$ & 233933 & 6030 & 2.6 \\
\hline Hastings & $34.5 \%$ & 90254 & 1159 & 1.3 \\
\hline Nottingham & $34.4 \%$ & 305680 & 26919 & 8.8 \\
\hline Wolverhampton & $34.4 \%$ & 249470 & 9062 & 3.6 \\
\hline Barbing and Dagenham & $34.2 \%$ & 185911 & 25520 & 13.7 \\
\hline Rockdale & $33.8 \%$ & 211699 & 29426 & 13.9 \\
\hline Hartlepool & $33.7 \%$ & 92028 & 689 & 0.7 \\
\hline Leicester & $33.6 \%$ & 329839 & 61440 & 18.6 \\
\hline Bradford & $32.6 \%$ & 522452 & 129041 & 24.7 \\
\hline Helton & $32.5 \%$ & 125746 & 267 & 0.2 \\
\hline Greenwich & $31.9 \%$ & 254557 & 17349 & 6.8 \\
\hline Lambeth & $31.2 \%$ & 303386 & 21500 & 7.1 \\
\hline Lewsiham & $31.0 \%$ & 275885 & 17759 & 6.4 \\
\hline Barrow-in-Furness & $30.9 \%$ & 69087 & 172 & 0.2 \\
\hline Penble & $30.7 \%$ & 89452 & 15579 & 17.4 \\
\hline Hynburn & $30.5 \%$ & 80734 & 8336 & 10.3 \\
\hline Brent & $30.5 \%$ & 311215 & 58036 & 18.6 \\
\hline Total Population & & & $1,217,958$ & 10 \\
\hline & & & & \\
\hline
\end{tabular}




\section{Economically Deprivation of the Muslims}

\begin{tabular}{|l|l|l|l|l|}
\hline Economically Active in Employment & \multicolumn{1}{|c|}{ All } & \multicolumn{1}{|c|}{ \% } & \multicolumn{1}{|c|}{ Muslims } & \multicolumn{1}{c|}{$\%$} \\
\hline Employed part times & 5,70111 & $12.5 \%$ & 236,206 & $13.0 \%$ \\
\hline Employed Full time & $15,858,791$ & $34.9 \%$ & 358,413 & $19.8 \%$ \\
\hline Self-employed Part time & $1,220,761$ & $2.7 \%$ & 71,452 & $3.9 \%$ \\
\hline Self employed Full time & $2,823,552$ & $6.2 \%$ & 99,466 & $5.5 \%$ \\
\hline Full time Student & 1,077353 & $2.4 \%$ & 65,759 & $3.6 \%$ \\
\hline (unemployed) & \multicolumn{1}{|l|}{----} & ---- & ---- \\
\hline Unemployed & $1,802,620$ & $4.0 \%$ & 130,553 & $7.2 \%$ \\
\hline Full Time Student & 334,167 & $0.7 \%$ & 37,801 & $2.1 \%$ \\
\hline (Economically Inactive ) & \multicolumn{5}{|l}{} \\
\hline Retired & $9,713,808$ & $21.4 \%$ & 104959 & $5.8 \%$ \\
\hline Student & 2397348 & $5.3 \%$ & 240248 & $13.3 \%$ \\
\hline Looking after Home Family or & 1796520 & $3.9 \%$ & 247729 & $13.7 \%$ \\
\hline Long Term Sick/Disable & 1783292 & $3.9 \%$ & 93179 & $5.1 \%$ \\
\hline Others & 987457 & $2.2 \%$ & 125164 & $6.9 \%$ \\
\hline All (ages 16-74) & 45496780 & \multicolumn{4}{|l|}{1810929} & 11 \\
\hline
\end{tabular}

The above-mentioned report shows that the Muslims are facing a lot of discrimination in the field of employment as compared to other population of the country. Level of unemployment among the Muslims is higher than the all others who belong to different religions as unemployment among local public is $4 \%$ only and among Muslims is $7.2 \%$. This denial of basic necessity for citizens, government is the responsible to offer equal opportunities of employment for all citizens. It is against the law that someone is discriminated due to his/ her religion.

According to the report of (Office for National Statistics) 2011, unemployment rate was different where compared religion wise: "Around Seven Percent of the Muslims and Six Percent of Buddhists and Hindus were student's unemployment compared with three percent of the Christians. The Jewish people and those with other religious affiliations $17 \%$ of economically active Muslims were un-employed (including unemployed students) Compared with around six percent of Christians and nine percent of people with no religion. The religion with the smallest proportion of people in this category was Jewish at four Percent". ${ }^{12}$

The unemployment rate among the students belonging to different religion shows that the highest rate of unemployment is among Muslim students. This is a solid proof that the Muslims are ignored and deprived by different department around the country although many of them have nationality of England but they are being deprived due to their religion. This is against the local constitution of the country but the government does not show any seriousness to eradicate this issue.

According to "Tell Mama Reporting" 2013/14" England is not a safe country for the Muslims at all. They are being assaulted due to their religion and color of skin and hate crimes against the Muslims are increasing year to year. 
The Crime Survey for England and Wale's (CSEW) provides an estimate for the Number of hate crimes per year. The majority of these crimes are racially motivated. Not all of these hate crimes will come to the attention of the Police, so the number of offences recorded by the police is lower than in the CSEW: (2011/12 to 2012/13)

Estimated number of hate crime $=$

Racially or religiously motivated hate crime $=$ (Police) Recorded crimes 2012/13.

Total number of hate crime $=$

Racially or religiously aggravation offences $=$ Detections 2012/2013

Racially or religiously aggravation offences= Courts Proceedings (2012)

Racially or religiously aggravation offences= (Convictions) 2012

Racially or religiously aggravation offences $=$
278000 Per Year

185000 Per Year

42439 Per Year

30234 Per Year

13768PerYear

8898 Persons

6458 Persons $^{13}$

This report shows that more than 2.5 million hate incidents occur per year in England, the most of them against the Muslims but a minor number of accused are considered culprit form courts. After 9/11incident, number of racial attack against the Muslims increased rapidly, especially those Muslims were the target of these attacks who wear any Islamic symbol as beard, hijab or any other.

\section{According to the record of (ECHR) (European Commission for Human Rights)}

"After 9/11 and government response to such terrorist crimes. Muslims have been physically attacked and mosques vandalized or burnt in a number of countries. In the United Kingdom no less than eleven mosques were attacked after the London terrorist bombing on 7 July, 2005, and in France five mosques were attached with explosives or put to fire in $2006 " .{ }^{14}$

Although all European countries claim that they believe that all human beings are equal and everyone has equal rights before law. All human beings have freedom of religion but after 9/11 Islam was accused the religion of extremism.

Even 2007 was the worst for the Muslims of England: "On August 23, 2007, The United Kingdom, in Southampton, a driver attempted to hit 30-year old woman wearing traditional Islamic dress and a headscarf "15. "May 15, 2007 in Meer brook, Isma, a 23-year-old woman was repeatedly pouched in the face and head....... She believed that the motivation for the attack was the headscarf she was wearing ". 16

A big wave of hate crimes and discrimination arose against Muslims in the UK and level of hate crime increased $65 \%$ than past year. Some prominent incidents are presented as reference. I have divided these incidents in three categories.

\section{1-Physical Assault 2- Damage of Property 3-Verbal Abuse}

Attacking the Muslim Persons and Property or Institutions which have Muslim background.

Verbal abuse on Persons who are suspected of being, the Muslim faith. 
No.1 Assaults or attacks on persons of the Muslim Background.

i. "A Muslims woman, Umaimi Musa, was assaulted by women while she sat with a pregnant friend, Mary Marandran in a Glasgow Park ". .17

ii. "Two Asian men, aged 25 and 21, were verbally and physically attacked in the early hours of 1 January 2013, by two men and one woman after leaving Pub in Kent ". 18

iii. "Following an English Defense league demonstration in Cleckheeton on 17 March 2012, Seven Men were charged with Violent Disorder for acts Committed including hurling racist abuse at a motorist and his Passenger, spitting on the passenger throwing a drink at their car and chasing another Asian man and subsequently beating him when he fell to the ground". ${ }^{19}$

iv. "A 30 years old Asian woman was attacked in Colchester on 28 January 2013 when she was struck to the back of the head, causing her to fall to the floor, while her attacker shouted racist abuse at her".$^{20}$

v. "A 78 years Asian Women was physically assaulted by a man who committed a string offence in Aylesbury on June 2013". ${ }^{21}$

vi. "A cyclist tried to pull off a Muslim woman's face veil as he rode past her near Victoria Park in Leicester on 26 May 2013". ${ }^{22}$

vii. "The Victim was walking to the park with her family at the time of the incident. Two men on bikes rode toward them and one of the men reached out and grabbed the Victim's veil as they rode post. The Victim managed to push him away and the men rode off ". 23

viii. "Ahmed Farhan was assaulted as he left London Underground's station on 18 August 2012. As he left the train, The Victim became wary of a group of men who stepped off the train". ${ }^{24}$

ix. "A 36-year-old Asian taxi driver, Mohammad Afzal, was attacked and racially abused by three men after picking up a fare at a Pub in Glasgow on 24 May $2013 " .25$

x. "A 55-year-old woman was brutally attacked on her way home in Mayfair, London, on 29 July 2-13; during Ramadan.

Response received by email from Abid Choudury, Islamic Human Rights Commission, 28 August 2013", ${ }^{26}$

In above reported incidents, it is observed that the Muslims are not safe in England and they are now totally insecure around the country. The Muslim minority is being targeted by local groups and organizations who dislike Muslims and consider them terrorist. They physically attack those Muslims who are by look more affiliated to Islam. The Muslim women are the main target of these attacks who wear hijab or head scarf at public places. They also target Muslim when they are with their families in parks, walking along the road, shopping in the markets, going to worship places, bus and railway stations and visiting places. Government is not taking solid steps to protect Muslim minority. This a very strange and sad reality that above mentioned all incidents reveal that no one of them was harming or provoking anyone that might 
cause of assault or attack due to his/ her offensive behavior. There is no evidence that Muslim minority violate the rule of the country or harm other citizen. They do not harm others instead of all this they are attacked and insulted by the native people.

\section{No.2 Attacks on the Muslim Property or institution -}

i. "A Pig's head was left outside a mosque in Newbury, Berkshire, on 232012 ". 27

ii. "Two men and a woman were sentenced for attacking bacon strips inside on 13 January 2011 “.28

iii. "A 43-year-old man was charged with religiously aggravated harassment after leaving a Pig's head in the car park of North Jām'ia Mosque in Watford during evening prayers on 21 February 2013". ${ }^{29}$

iv. "An investigation was launched by the North Wales Police after a garage behind Shafiul Islam's home in shotton was torched on 2 April 2013" ${ }^{30}$

v. "Jām'ia Masjid Suafia Mosque in wake-Field was vandalized with unspecified food thrown at the side of the building on 4 April 2013".31

vi. "The letters "EDL" were daubed in grey pain on a Mosque in Bedminster and in red Paint on a Sikh temple in Red field. Both were vandalized with the graffite between 21 and 25 September, 2012".32

vii. "Two men were arrested on suspicion of criminal damage after window of a mosque on Road in Wakefield. West Yorkshire was smashed in May 2013 “.33

viii. "Strips of bacon were left at the entrance of Shah Jalal Mosque in Cardiff on 22 May 2013 “.34

ix. "The Windows of Mosque in Grimsby were damaged following a Party 0223 May 2013. A number of Parked Vehicles were also damaged and bins were overturned A Fast-food outlet in east London owned by a Muslim family was attacked on the night of 23 May 2013". 35

The Muslim minority is already economically deprived and along with this, they are being attacked and harassed while at work places by their colleagues and others. The aggressive groups of native population attack not even the Muslim minority but also the Muslim places of worship. Mosques are being targeted, sometimes they set fire in Mosques and sometime write hate slogans on walls. It is prohibited in Islam to use the meat of pig so due to this reason they throw pig head in Mosques and sometime they burn the Holy Quran too. This is against their own national law and U.N.O laws of the minorities which they have signed to obey. Muslim minority is not enjoying religious freedom. Although the Muslims are taking part in the progress and prosperity of the country, the native public consider them danger for their economy, so the attacks on the Muslim properties is common.

\section{Verbal abuse and Hate speech}

i. "A man who tore pages from his copy of the Quran at a bookstall in Leicester City Center was charged with religiously aggravated in intentional harassment, alarm or distress by demonstrating hostility based on membership of a particular group of 12 May 2012".36 
ii. "Two men and a woman burst in to the Nair Mosque in Hart Liverpool and Shouted racial abuse on the evening of 5 February 2013. They entered the Mosque through the main entrance and caused a distrubance by shouting during prayer. When asked to leave, the group became racially abusive towards worshipers " 37

iii. "An unidentified woman hurled racial abuse at passenger on a London underground tube which was filmed by a fellow Passenger and posted onto YouTube Promoting an Investigation by British transport police" 38

iv. "A 48-year-old man passed a series of offensive messages on Facebook encouraging People to attack businesses run by the Muslims" ${ }^{39}$

v. "A 24-year-old woman passed racist comments on Facebook in June 2013.

Michaela Turner Posted the Comment: Feeling like Burning down some Mosques in Portsmouth, anyone want to join me". ${ }^{40}$

vi. "A 25-year-old man. posted a message on Facebook about a Mosque in Grimsby being burned down on 24 May 2013". ${ }^{11}$

vii. "A man was convicted of racially aggravated offences after threatening to burn down a Mosque". ${ }^{42}$

viii. "A drunken woman and a man hurled racist abuse at staff in take way shop in Cleethorpes on 4 June 2013" ${ }^{43}$

ix. "Football Fans allegedly tore out pages from a copy of the Qur'an and ripped them to pieces during a club match at middles brought Football club on 7 December 2013”.44

x. "An arson attack on a proposed mosque in Bristol was advocated in Comments posted on the webpage of the English Defense League Bristol Division on 4 December 2013. Islam phobia watch, 11 December 2013". ${ }^{45}$

The number of verbal abuses and hate speech incidents is massive because these incidents are normally not reported for any investigation. In routine life everywhere around the country the Muslim minority face verbal abuses by the native citizens. The Muslim men and women who apparently look like proper Muslim are the focused target of these un-pleasure incidents and they may face such type of harsh comments or verbal abuses many times in a week or month at work places, while shopping, during travel, on visiting places and seeking for job.

In $ء 2013$ incidents of physical attacks, property damage and verbal abuse are so many, it is not possible to write all here because many of them are off the record but from these incidents we can observe that the Muslim minority is facing discriminated behave in the field of economy, politics, religion and culture.

In England crime rate is increasing rapidly every year. The Muslim minority has no equal rights although national and international law give equal rights for all types of minorities in every field of life but the UK government has totally failed to provide basic rights to Muslim minorities and to protect them as other citizens. Survey reports shows that in 2011 that $25 \%$ of total hate incidents were only against the Muslim minority. 
i. In the United Kingdom, the Police have been recording data on hate crimes since 2008, and 4 out of the 43 Police forces also disaggregate the hate crimes into categories. "In 2011, total of 44,361 incidents were registered. Additionally, a minimum of 1,773 cases were recorded as religious hate crimes. The further breakdown based on these official figures showed that 52 Percent of the cases were hate crimes targeting the Muslims, 26 percent target Jews and 14 percent targeted Christians". ${ }^{46}$

ii. This report reveals that after 9/11 mosques, Islamic centers and the Muslim NGOs often have been targeted. The researchers of university of Exeter has claimed that after 9/11 each year about 100 to 200 mosques and Islamic centers have been targeted every year. This thing shows that UK has become the land of non-Muslim introverts who do not accept the Muslim minority in their country.

The Authors of a university of Exeter report on Anti-Muslim Hate crimes estimated that since 9/11 between 40 and 60 percent of British Mosque, Islamic Centers, and the Muslim organizations have experienced at least one attack that could have been reported as a hate crime. They corresponding assert that between 100 and 200 hate crimes against mosques, Islamic Centers and Muslim Organizations take Place every year, an estimate they describe as "Probably highly Conservative" The data set for 1st May 2013-28 February 2014 Includes 734 self-reported cases of these, there were 599 incidents of online abuse and 135 reported offline incidents. The offline incidents included 23 causes of assault, and another 13 involving extreme violence- two fifths of all the cases (both online and offline) were associated with far right groups.

\section{Terrorism Act and Muslim community in U.K.}

Western media negatively portrait Islam and Muslims. The local British public consider Muslims danger for them and security risk for their country. The Government of the UK has introduced a law named "Terrorism Act 2000" to control the terrorism. This law has two special sections (A44 and S43) due to these sections the UK security forces can stop, search and interrogate anybody around the country. This law is being misused against the Muslim minority. The Muslim minority is being targeted at airports, seaports, bus stands, railway stations and other public places. Those Muslims are the special target of the police who have beard or Islamic get up. This report shows the total number of those who were stopped and interrogated.

Use of (S44) stop and Search Table

\begin{tabular}{|l|l|l|l|}
\hline Year & (S44) Stops and & Arrests for & Conviction for \\
\hline$/ /$ & Searches & Terrorism & Terrorism offences S44 \\
\hline$/ /$ & $/ /$ & offences from S44 & \\
\hline $2001 / 02$ & 10,200 & 20 & 0 \\
\hline $2002 / 03$ & 32,000 & 19 & 0 \\
\hline $2003 / 03$ & 33,800 & 19 & 0 \\
\hline $2004 / 05$ & 37,000 & 64 & 0 \\
\hline $2005 / 06$ & 50,000 & 105 & 0 \\
\hline $2006 / 07$ & 42,800 & 28 & 0 \\
\hline
\end{tabular}




\begin{tabular}{|l|l|l|l|}
\hline \hline $2007 / 08$ & 126,500 & 19 & 0 \\
\hline $2008 / 09$ & 210,000 & 9 & 0 \\
\hline Total & 542,400 & 283 & $0 \quad{ }^{47}$ \\
\hline
\end{tabular}

This report shows that 550000 were stopped and searched under this law, but not a single one was found guilty. This law was dismissed in July 2010 because it was against the law (respect for private and family life). This shows that it was basically against the law of England, but instead it was being implemented for ten years.

\section{Terrorism Act 2002:}

Under schedule 7 of this Act persons of different racial backgrounds were arrested and interrogated from 2010 to 2014.

Examined More than 1 Hour

\begin{tabular}{|l|l|l|l|ll|}
\hline Sr. no. & $\mathbf{2 0 1 0 / 1 1}$ & $\mathbf{2 0 1 1} / \mathbf{1 2}$ & $\mathbf{2 0 1 2 / 1 3}$ & $\mathbf{2 0 1 3} / \mathbf{1 4}$ \\
\hline White & $14 \%$ & $12 \%$ & $14 \%$ & $11 \%$ & \\
\hline Black & $15 \%$ & $14 \%$ & $14 \%$ & $19 \%$ & \\
\hline Asian & $45 \%$ & $36 \%$ & $33 \%$ & $32 \%$ & \\
\hline Other & $20 \%$ & $24 \%$ & $25 \%$ & $25 \%$ & \\
\hline Mixed/not stated & $6 \%$ & $14 \%$ & $15 \%$ & $13 \% \quad .48$ \\
\hline
\end{tabular}

We can say that the UK has law for minorities to treat them equal but it is only in the book of law. It is not practically implemented in England. The Muslim minority is living in very miser conditions. They are not considered citizen of country. They are treated as guest worker there. They are living in substandard houses. They cannot get equal chances to find a job as the local citizens have. They can not avail proper health facilities and they are being treated as second class citizens. They cannot perform religious rites freely. They are not economically well settled. They have to face discrimination in every field of practical life.

\section{Conclusion:}

This study perceives that the Muslims living in England have no equal rights as local citizens have. Sometime the Muslim minority has rights in written but not in practical life. Muslim minority is facing serious discrimination in all perspectives. They feel themselves inferior to native people because the public and government both behave unequal to them. Muslims were almost living peacefully before 9/11, but after this incident, they are not safe in England in bazar, market, playground, job places, Educational institutions and even walking alongside the roads. They are being suspected at bus stands, airports and hotels. They are stopped, harassed, investigated and interrogated only due to unreasoning suspicion. Terrorism is patched with Islam and worship places of the Muslims are under attacks. The Muslim women, who wear hijab are being attacked and insulted by the local citizens. In practical life, Muslim community in England has no equal rights in social, political and economic life.

\section{Recommendations:}

1- The United Nations Organization should bound, the western countries to not only adopt (UNO) charter of minorities but also they should implement it practically. 
2- The Muslims in the UK should unanimously struggle for their social, political, economic and religious rights.

3- To create religious harmony all human beings should be given rights according to their religion.

4- European Union and the UK government should take firm steps to eradicate negative propaganda against Islam and the Muslim minority.

5- UK government should set some norms for media to stop media trial of the Muslims as this has become habit to blame Muslims and Islam without investigation.

\section{References \& Notes:}

${ }^{1}$ Nabil Matar, Islam in Britain, 1558-1585 (Cambridge: Cambridge University Press, 1998), p.87

${ }^{2}$ https://sites.cardiff.ac.uk/islamukcentre/rera/online-teaching-resources/muslims-in-britain-onlinecourse/module-3-communities/diversities/muslim-ethnicities/retrievied/Accessed on 10-08-2019.

${ }^{3}$ Pew Research Centre, Global Religious futures Project, Report No 13.

${ }^{4}$ Census 2011, ONS Table KS209 IEW, UK, Office for National Statistics (GB)

https://www.ons.gov.uk/census/2011census. Accessed on 12-08-2019.

${ }^{5}$ Pew Research Centre: It is a nonpartisan American think tank based in Washington, D.C. It provides information on social issues, public opinion, and demographic trends shaping the United States and the world. It also conducts public opinion polling, demographic research, media content analysis, and other empirical social science research. The Pew Research Centre does not take policy positions.

${ }^{6}$ Census 2001, ONS Table KS1048, UK, Office for National Statistics (GB)

https://www.ons.gov.uk/census/2001census. Accessed on 21-03-2019.

${ }^{7}$ Ibid.

${ }^{8}$ Population in Prison Establishments, June 2012 House of Commons Library Note SN/SG/4334, 2013

${ }^{9}$ Khan, S.M., Muslims in Prison, (Q-news, October, 2000 p.9") "BMMs, (June 2001) 4-5

${ }^{10}$ Population in Prison Establishments, June 2012. House of Commons Library Note SN/SG/4334, 2013

${ }^{11}$ Ibid, (July 2013)

${ }^{12}$ Census2011 ONS Table Dc 6205EW, Office for National Statistics (GB)

${ }^{13}$ Office for National Statistics, Full story: What does the Census tell us about religion in 2011, (16 May 2013)

${ }^{14}$ https://www.infoplease.com/us/government/post-911-changes-by-the-us-government/18-8-19

${ }^{15}$ Driver Attempts to run women over, BBC News, August 21, 2007, Tad Stahnke, Paul LeGendre, Innokenty Grekov, Michael McClintock, and Alexis Aronowitz, Human Rights First, Violence against Muslims, Hate Crime Survey, 2008. P.78.

${ }^{16}$ Ibid, P .71.

${ }^{17}$ OSCE Submission (2013), Human Rights First, Violence against Muslims, annual report 2013, P.43.

${ }^{18}$ Ibid, P.45.

Human Rights First is a nonprofit, nonpartisan international human rights organization based in New York and Washington D.C. To maintain our independence, we accept no government funding.

${ }^{19}$ ENGAGE OSCE Submission (2013) - incident reference 1.22 P.9, Ibid, p.22.

${ }^{20}$ Daily Gazette, (3 February 2013) https://dailygazette.com/archive-search/Accessed on 20-8-19

${ }^{21}$ Leicester Mercury, (11 June 201). https://www.leicestermercury.co.uk/news/history/ accessed on 2604-2019.

${ }^{22}$ Human Rights First, Violence Against Muslims, annual report 2013, P.22.

${ }^{23}$ Freedom of information request, Police Scotland reference IM-FOI-2014-1797. 
${ }^{24}$ ENGAGE OSCE Submission (2013) - incident reference 2.16 P.15-16. Human Rights First, Violence Against Muslims, annual report 2013, P.11.

${ }^{25}$ The Scotsman, (4 February 2013), Hate Crimes in the OSCE Region: incidents and responses, Annual report 2013, Office for Democratic Institution and Human Rights (ODIHR), P.66. (OSCE) organization for security and c-operation in Europe serve as a collection point for information and statistics on hate crimes and make this information publicly available. Thus, its purpose is to provide hard data and other information about the extent and types of hate crimes in the OSCE region in 2011

${ }^{26}$ Muslim News, (February 2013), Hate Crime Data Collection practice across the Europe, European Union Agency for Fundamental Rights, Annual Report 2011, P.97. This report provides an overview of practices regarding recording and collecting data on hate crime in all 28 EU Member States, as well as of how law enforcement agencies cooperate with civil society organization in this regard.

${ }^{27}$ ENGAGE OSCE Submission (2013) - incident reference 2.16 P.15-16.

${ }^{28}$ The Scotsman, (4 February 2011). Hate Crimes in The OSCE Region: incidents and responses, Annual report 2013, Office for Democratic Institution and Human Rights (ODIHR), P.50.

${ }^{29}$ Muslim News, (31 March 2013), Hate Crime Recording and Data Collection practice across the Europe, European Union Agency for Fundamental Rights, Annual Report 2013, P.99.

${ }^{30}$ BBC News, (21 May 2011) Hate Crimes in The OSCE Region: incidents and responses, Annual report 2013, Office for Democratic Institution and Human Rights (ODIHR), P.44.

${ }^{31}$ Wakefield Express, (11 April 2013), P.101.

${ }^{32}$ Anti-Muslim Hate Crime, https://www.mend.org.uk/wp-content/uploads/2017/04/Hate-Crime-

Report-2013.pdf Accessed on 17-8-19.

${ }^{33}$ Wakefield Express, (18 May 2013). https://www.wakefieldexpress.co.uk. Accessed on 11-07-2019.

${ }^{34}$ Wales Online, 23 May 2013.

${ }^{35}$ Grimsby Telegraph, (25 May 2013). Hate Crime Recording and Data Collection practice across the Europe, European Union Agency for Fundamental Rights, Annual Report 2013, P.98.

${ }^{36}$ New Ham Recorder, (24 May 2013). Hate Crime Recording and Data Collection practice across the Europe, European Union Agency for Fundamental Rights, Annual Report 2013, P.96.

${ }^{37}$ Leicester Mercury, (11 January 2013). https://www.leicestermercury.co.uk/news/history/ accessed on 27-07-2019.

${ }^{38}$ Daily Mail, (22 April 2013). https://www.dailymail.co.uk/home/sitemaparchive/month_2013-04.html ${ }^{39}$ Ibid, (23 May, 2013).

${ }^{40}$ The Guardian, (14 June 2013). https://www.theguardian.com/global/2013/jun/11/guardian-weeklyletters/ accessed on 22-08-2019.

${ }^{41}$ Grimsby Telegraph, (18 July 2013). https://www.grimsbytelegraph.co.uk/ accessed on 20-07-2019.

${ }^{42}$ Cambridge News, (16 August 2013). https://www.cambridge-news.co.uk/ accessed on 29-07-2019.

${ }^{43}$ Grimsby Telegraph, (24 August 2013). https://www.grimsbytelegraph.co.uk/ accessed on 29-07-2019

${ }^{44}$ The Guardians, (28 February 2013). https://www.theguardian.com/global/2013feb/11/

${ }^{45}$ The Bristol Post, (13 December 2013).

${ }^{46}$ Nigel Copsey, Anti-Muslims hate crimes and the far right (Middles Brough: Teesside University, (2013), 8.

${ }^{47}$ Tufyal Choudary and Helen Fenwick, Equality and Human Rights Commission report, research Report 72, the impact of Counter terrorism measures on Muslims Communities, Arnald Centre Manchester, (2011) 93-94.

${ }^{48}$ David Anderson Q.C., The Terrorism Acts in 20013, "Report of the independent reviewer on the Operation of the terrorism Act $₫ 2000$ and part 1 of the Terrorism Act $₫ 2006$.

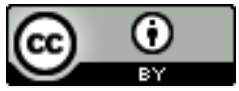

This work is licensed under a Creative Commons Attribution 4.0 International License. 